\title{
Minority within a Minority: Shia Community in Ukraine
}

\author{
AKIF TAHIIEV 1
}

\begin{abstract}
Ukraine is one of the largest countries in Europe and there is a significant Muslim minority here, among which there are several Shia communities. Aspects of the life and activities of the Shia community in Ukraine are almost unexplored. Although at the same time a number of studies were devoted to the Shiite minorities of Western European countries, therefore in this paper, we examined the characteristics of the life of the Shia community in Ukraine and compared it with the characteristics of the Shia communities in Western Europe. Special attention was paid to the peculiarities of the mentality of the indigenous Shiites, represented by Azerbaijanis. The features of the institutionalization of the Shia communities of Ukraine, the features of conducting divine services and mourning events of Ashura were considered. After analyzing the above problems, we came to the conclusion that the Shiites of Ukraine are more passive, so we tried to identify the reasons for such passivity, among which the most important are the Soviet "atheistic" past; cultural, national and linguistic diversity of representatives of the Shiite minority of Ukraine, which prevents larger gatherings of Shiites from being held. We consider the article as a basis for further research in this region, therefore, the purpose of the study was to highlight all possible problematic aspects of the life of Shiite minorities in Ukraine.
\end{abstract}

Keywords: Islam in Europe, Shia, Shiites/Shiism, Ukraine, Azeris (Azerbaijanis).

Ukraine is one of the most populated countries in Europe (State Statistics Service of Ukraine. 2020). The location of Ukraine between Europe and Asia, between "western" and "eastern" cultures contributed to the country's religious and cultural diversity and the formation of a community of ethnic Muslims with a 500-year history in it (Crimean Tatars). That is, Muslims belong to the indigenous ethnic group and religion of Ukraine. In Ukraine, there are 40 ethnic groups that traditionally profess Islam, the largest of which are the Crimean Tatars $(248,000)$, Volga-Ural Tatars $(73,000)$ and Azerbaijanis $(45,000)$ (Muratova 2011).

Muslims make up 1-2\% of the country's population. In general, more than 1 million Muslims live in Ukraine, among whom Shiites are a minority. Counting the exact number of Shiites and Muslims, in general, is complicated by a number of factors. The last official population census in Ukraine was conducted in 2001 (State Statistics Committee of Ukraine 2001). and was differentiated only by ethnicity, that is, there was no official population census based on religion in Ukraine. In addition, given the fact that Muslims represent a significant minority in Ukraine, the main interest of researchers is directed at Christian communities, especially the relationship between different groups of Orthodox churches (Ukrainian Institute of Strategies of Global Development and Adaptation 2019). It also follows from the previous factor that the Muslim community of Ukraine seems to be something whole and indivisible, therefore, Ukrainian researchers generally do not consider the Shia group as a separate community. In recent years, due to the political situation, it seems impossible to calculate information about the population of the Autonomous Republic of Crimea, Donetsk and Luhansk

${ }^{1}$ Akif Tahiiev Ph. D. candidate. The Department of International Private Law and Comparative Jurisprudence, Yaroslav Mudryi National Law University, Kharkiv, Pushkinskaya str., 77, KHARKIV 61024, Ukraine. Email: akiftagiev96@gmail.com

https://doi.org/10.24035/ijit.19.2021.191 
regions, and as the data show, it was in these regions that the majority of Ukrainian Muslims (including Shiites) lived (Bogomolov 2005).

In this paper, we examined the peculiarities of the life of the Shia community in Ukraine, namely, the peculiarities of the functioning of Shia religious centers. We also constantly compared certain features of the Shia minority in Ukraine with the Shia minorities in Western Europe. The big advantage of this study is the fact that its results can be projected on other countries of Eastern Europe (Russia and Belarus) and Central Asia since the situation with Shia minorities in them is practically similar, which is due to the common Soviet past and the secular vector of governance in the current independent countries of this region.

\section{Historical Background and Ethnic Composition}

Ruthven \& Nanji 2004 noted: "Shiites are concentrated in Iran, southern Iraq, Kuwait and Bahrain, with significant minorities in Afghanistan (3.1 million or 15\%), India (3\% or $30,000,000)$, Lebanon ( $34 \%$ or 1.2 million), Pakistan $(20 \%$ or $28,000,000)$, Syria $(12 \%$ or 2 million), Turkey ( $20 \%$ or 3 million), the United Arab Emirates (16\% or about half a million) and Yemen $(40 \%$ or $7,000,000) "$. Also, Shiites make up the majority of Muslims of Azerbaijan (approximately 6.5 million or $67 \%$ of the total population) (Yunusov 2019).

Muslims have lived in Ukraine for many centuries, but the majority of them are Sunnis. In Western Europe, Shiite Muslims appeared mainly from Iran, Arab countries and South Asian countries as a result of labor migration. In Ukraine, such phenomena manifested themselves only in labor migrations from other countries of the post-Soviet space, where Azerbaijan was the only country with a Shiite majority. That is why ethnic (that is, who have not been living in Ukraine for the first generation) Muslim Shiites are mainly Azerbaijanis. It is almost impossible to determine their exact number. Using the method of calculating the number of Azerbaijanis in Ukraine (by ethnicity) will not give the expected result, since among Azerbaijanis there is a very large Sunni community and a large number of Azerbaijanis do not have sufficient religious education, which leads to the loss of their Shiite identity and consciousness. Thus, one of the Sunni leaders of Ukraine, Said Ismagilov noted in an interview that "there are not many Shiites in Ukraine. There are communities in Kyiv and Kharkiv. Shiites are mostly Azerbaijanis. Unfortunately, the majority of Azerbaijanis are rather weakly religious (Sheikh Said Ismagilov. 2016).

The lack of religiosity among Azerbaijanis is caused by the loss of Shiite identity, which was a consequence of being in the USSR for 70 years and the secular policy of modern Azerbaijan. The same thing happened in other Muslim republics of the USSR. Thus, Zhussipbek (2017) writes that the last decades have been marked by the revival of Islam in post-Soviet Central Asia after 70 years of systematic extermination and suppression by the Soviet regime of religious institutions, educational centers and Islamic identity through the use of comprehensive social projects. In the early years of the Soviet Union, as soon as Soviet power was established in the Caucasus and Central Asia, the "curtain" separated these territories from neighboring Muslim countries. The borders were closed, and all contacts between Soviet Muslims and their fellow believers were prohibited. Visits by Soviet pilgrims to shrines in Karbala, Najaf and Mashhad have ceased since 1925 (Akhmadullin 2013: 156). Although, according to other sources, this happened even earlier and since 1920 the pilgrimage to Mecca was stopped, as well as the pilgrimage of Azerbaijani Shiites to the holy places of Iran and Iraq. After the war, the pilgrimage to Mecca was restored but limited to one plane per year, specially hired for this purpose, that is, only 30-40 pilgrims, specially selected among the ministers of four spiritual Muslim departments (Fayzrakhmanov 2009: 21-22). Pilgrimage to Shiite shrines was briefly resumed in May 1945, when, with the permission of the Soviet authorities, three leaders of the Spiritual Directorate of Muslims of Transcaucasia made a trip to the cities of Iran (to the shrines of Mashhad and Qom) (Akhmadullin 2015: 37). In the 1950-60s. attempts were made to organize pilgrimages for Shia Muslims, but this did not yield results: the Commissioner

$$
\text { https://doi.org/10.24035/ijit.19.2021.191 }
$$


of the Council for the Affairs of Religious Cults in the Azerbaijan SSR M. R. Mamedov proposed to resume pilgrimage trips to Mashhad and Karbala and informed the Council that there are those who wish to make the pilgrimage to Mashhad and Karbala. In 1956, the Spiritual Directorate of Muslims of Transcaucasia received 28 applications for a pilgrimage to Mashhad and 50 applications from those wishing to visit Karbala (Akhmadullin 2016: 53-54). Due to the lack of Shiite madrasas and Islamic universities, those wishing to become Shia religious clerics were forced to study in Sunni educational institutions. After the collapse of the USSR, freedom of religion was proclaimed in the post-Soviet countries. Azerbaijan took a course of secularization similar to the Turkish one, which led to the fact that Muslim Azerbaijanis, who had no access to religious knowledge for 70 years, still remained religiously uneducated. Those wishing to receive religious knowledge or become clerics were going to Iran to study at Islamic universities. In fact, in Azerbaijan itself, any kind of pilgrimage is allowed and in some regions, public processions are held on the streets dedicated to the mourning of those killed in Karbala. At the same time, the government of Azerbaijan, fearing the strengthening of Islamists or revolutionary tendencies (due to the possibility of exporting the Islamic revolution from Iran), is suspicious of any form of manifestation of religiosity among the population - this, in particular, is related to the bans on wearing hijabs in certain institutions and dubious arrests of some individuals. The main reason for these fears is the policy of Muslim countries, including Azerbaijan's neighbor, Shiite Iran. Dina Lisnyansky notes that shortly after the Islamic Revolution, the new Iranian regime formed organizations to promote the idea of uniting all Islamic madhhabs and legitimizing the Jafari madhhab within a common Islam that would embrace both Sunnis and Shiites. The sense of these efforts was as follows: since a Sunni Muslim can accept the authority of any Sunni sheikh, no matter to which madhhab he follows, a Sunni could follow the authority of a Shia scholar if the Jafari madhhab were considered on a par with the Sunni ones. And he could do this without crossing the line and becoming a Shiite (Lisnyansky 2009).

The rest of the Shiite groups in Ukraine are represented mainly by students from countries with a Shia population - Lebanon, Iraq, Iran, India and Pakistan. There are also migrants from these countries. The fact that the majority of Shiites, apart from Azerbaijanis, arrive in Ukraine only for some time (most often during their studies) is one of the main reasons why the Shiite minority is practically unnoticed. The transition of Ukrainians and Russians to Shiism in Ukraine is a rather rare phenomenon, although such cases are known (Dmitruk 2016). This is due to the fact that the Shiites of Ukraine are more focused on their community in the sense that they are not engaged in such active propaganda of Islam, in contrast to the same Sunnis in Ukraine. The Shia population of Ukraine is represented mainly by Twelver Shiites. Even if Ismailis and Zaydis arrive in Ukraine, most often they join religious events of either other Shia or Sunni groups.

\section{Shia Organizations and Centers}

In Ukraine, the activities of religious organizations envisaged by law, and there is a special register that lets you know how many religious groups and of which direction exists in Ukraine. It should be noted that many organizations and groups are not institutionalized, that is, they do not create "religious organizations" in accordance with the legislation of Ukraine, and so it is very difficult to document their activities. But based on the registry information, researchers have the opportunity to draw up an overall "picture" of the country's religious diversity. Muslims do not have a unified management structure on a Ukrainian scale, although Sunni organizations unite into spiritual administrations. At the beginning of 2013, there were six spiritual Muslim centers (Ministry of Culture of Ukraine 2012). As of January 1, 2019, 73 religious organizations and 8 religious associations were registered in Ukraine, including 173 religious organizations (Department for Religions and Nationalities of the Ministry of Culture of Ukraine 2019). Thus, in total there were 246 registered Sunni organizations in Ukraine and only

$$
\text { https://doi.org/10.24035/ijit.19.2021.191 }
$$


9 Shiite ones. Shia organizations are not hierarchical, so they operate autonomously, mainly distributed in different regions of the country.

Bøe and Flaskerud (2017) using the example of the development of Shia mosques and associations in Oslo, write that usually, when the Shia community is small, believers of different nationalities and cultural backgrounds gather in one place. However, as the community grows, as a rule, divisions arise by language, culture, and sometimes by theological convictions, for example, by following different Marja at-Taqlid (source of imitation). Such a situation is not typical for Ukraine, since in Ukraine initially there was a "division" of Shiites into the Azerbaijani group and representatives of other nationalities, and each of the groups held their meetings in their own language, which would complicate the involvement of representatives of other nationalities. Let's consider this situation using the example of the Shia communities of the city of Kharkiv.

\section{The Shia Population of Kharkiv}

Kharkiv is the second (after Kyiv) city in Ukraine in terms of population and is a multinational city in which representatives of more than 100 nationalities live. We chose the city of Kharkiv for analysis since it is in it that the largest Shia community in Ukraine, including the Azerbaijani one, lives. In fact, there are Azerbaijani communities in almost all cities of Ukraine, but in most of them, there are no Shiite organizations or religious buildings. The Shia community of Kharkiv consists of Azerbaijani and Arabic (represented by immigrants from Lebanon and Iraq). There are also Iranians, Indians and Pakistanis, who, due to their small number, most often join the two more numerous. Considering the fact that the second group (that is, non-Azerbaijanis) is represented mainly by visiting students, their meetings are mainly held only on special days, most often the first ten days of the month of Muharram, associated with memorial rites due to the tragic death of Imam Hussein in Karbala.

The majority of Azerbaijanis live in Ukraine on a permanent basis, and, in turn, have their own religious buildings, the central of which is the Shiite mosque of Imam Ali, which is often referred to in the media as the "Azerbaijani Mosque". This mosque operates regularly, weekly Friday sermons and prayers are held, all holidays and mourning days are celebrated in accordance with the Shia religious calendar. All sermons and processions take place in the Azerbaijani language, while representatives of the Arab community conduct their events in Arabic, respectively. We believe that the language barrier is one of the main obstacles to the greater unity of the multi-ethnic Shia community of Kharkiv. Schlatmann (2017) pointed out that the big problem facing this community is the lack of sermons in the Dutch language and the clergy who are fluent in it. But here one should take into account the fact that the Shia communities speak Dutch and the younger generation is less and less able to speak the language of their parents, that is, the country of which they come from, so they have a need for clergy in their native language. But, as in the Shia imams of mosques in Ukraine, the Dutch are trained in the Hawzas (a seminary where Shi'a Muslim clerics are educated) of Iraq or Iran and most often learn only Arabic and/or Farsi. The main languages of communication in Kharkiv are Ukrainian and Russian, and in Sunni mosques, sermons are mostly conducted in Russian. For the Shia communities, the situation is different. Representatives of the Azerbaijani community for the most part speak Russian, but not at the level to assimilate sermons, which most often sound in the literary language, and not in the spoken language. In addition, they have their own cultural heritage in the form of verses and marsiya - mourning chants in the Azerbaijani language (there are only a few of them in Russian). Since the representatives of the second community are mainly students who stay in Ukraine temporarily and mostly study in English, they do not speak Russian, therefore, even if the sermons are conducted in Russian, they are unlikely to attract the attention of a large number of representatives of this community. Perhaps soon this barrier will be overcome, and the Shia communities of Kharkiv and Ukraine as a whole will unify in linguistic terms. 


\section{Ashura in Kharkiv}

Mourning events in the month of Muharram are one of the most important aspects of Shia identity around the world. In many countries, Shiites conduct processions on the streets, including in non-Muslim countries. It is obvious that for representatives of a non-Muslim society, these processes may seem interesting, but at the same time and strange. Therefore, young Shiites are redefining religious practices through public speaking and embodied experience in British society (Spellman-Poots 2012). This can be manifested in the conduct of actions against terrorism instead of the processions, or educational activities (an acquaintance of non-Muslims with the history of Karbala events), or holding actions like "Who is Hussein" - a social justice movement striving to build a compassionate \& selfless society through volunteer teams in over 90 cities worldwide. Here, certain contradictions may arise between the cultural characteristics of these mourning events. Public self-flagellation and bloodshed were a controversial issue not only between Sunni and Shia Muslims but also between various Shia communities and clergy, as it relates to discussions of "barbarism" and "modernity" (Weiss 2010). Sufyan Abid Dogra, in an article on Ashura in London, wrote about the dissatisfaction of some Shiites who came from regions where the practice of bloodshed was acceptable, due to the ban on such procedures (Dogra 2017). In some countries, Shiites donate blood for medical needs instead of these procedures, considering it more appropriate in modern conditions (Flaskerud 2016).

In Ukraine, Shiites do not hold public processions and mourning events are held in mosques, in Hussainia or in specially rented premises adapted for Hussainia. Self-flagellation and bloodshed are absent, and mourning events most often consist of prayers, reading the Quran, sermons and chants (marsiya), accompanied by "matam" - symbolic blows to the chest as a sign of sorrow. There is no practice of tatbir (bloodshed), although in some places, individuals use chains with small blades, but this does not lead to bloodshed. Some local imams do not welcome the latter practice. For Shiites, Ashura has a strong cultural color besides religious. So, it is on these ten days of Muharram that Shiite gatherings are most numerous - even lessreligious Shiites come to attend these meetings. For most of them, this is a tribute to traditions, which, mainly for Azerbaijanis, is the result of secularization and many years of secular politics in their countries. Even taking into account the fact that traditions are a rather flexible phenomenon (some are invented, others are attributed with a meaning that they did not have before), they played a major role in the process of articulating national identity in historical and cultural contexts. Islam is dependent on national identities (Khalid 2012). In fact, most of the practices of self-flagellation are precisely cultural in nature, although over time they acquired a somewhat religious coloration, which significantly damaged the reputation of the Shiite trend of Islam.

To conclude, after analyzing the above information, we come to the conclusion that the Shiites of Ukraine are more passive than the Shiites of Western European countries. This is due to a number of reasons. The main one is the lack of unity among the representatives of the community. This is manifested in the division of the community according to nationality and, as a consequence, language. Because of this, Shiite gatherings become less numerous, since in fact a small community itself is realized in the form of small group gatherings. This leads to the fact that these gatherings go unnoticed by representatives of the media, the public and other faiths. The active transition of the local population to Shiism also does not occur due to the "concentration" of the community on the current members, although individual cases of such a transition are known. Also, the influx of foreigners has a serious impact on the life of the Shia community, since it is they who make up a significant part of the Shia community. A significant part of the Shia community of Ukraine, represented by Azerbaijanis, consists of both religious people (observant Muslims) and a large number of non-observant ones. 
We believe that the main problem of the Shia community in Ukraine is the language barrier and the passivity of local Shiites. Still, there are prerequisites for the formation of Ukrainian Shiite identity. They are manifested in a new generation of young Shiites, represented by Azerbaijanis and foreigners who have remained to live in Ukraine. Both of these groups will be fluent in Russian or Ukrainian, which will contribute to the consolidation of the Shia community, which, as a result, may lead to the formation of a larger network of Shiite religious organizations (possibly even a certain kind of educational institutions). This, in turn, can cause greater interest in Shiism among the indigenous population and a more active transition of the latter to Shia Islam.

\section{References}

Akhmadullin V. A. 2015. Patriotic activities of the spiritual administrations of Muslims during the Great Patriotic War. Moscow: Islamic book.

Akhmadullin V. A. 2016. The activities of the Soviet state and the spiritual administrations of Muslims on the organization of pilgrimage (1944-1965): analysis of historical experience and significance for the present. Moscow: Islamic book

Akhmadullin V. A. 2013. Characteristic mistakes of researchers in the analysis of the Hajj of Soviet Muslims in 1945'. Power. No. 7: 156-158.

Bøe, Marianne \& and Flaskerud, Ingvild 2017. A minority in the making: The Shia Muslim Community in Norway. Journal of Muslims in Europe. 6 (2):179-197.

Bogomolov, A. et al.,2005. Islams'ka identichnist' v Ukra'ini (Islamic Identity in Ukraine). Kiev: AMES Publishers.

Department for Religions and Nationalities of the Ministry of Culture of Ukraine. 2019. Religious organizations in Ukraine, https://risu.ua/religiyni-organizaciji-v-ukrajini-stanom-na-1sichnya-2019-r_n97463. Retrieved: 17 December 2020

Dmitruk, Igor. 2016. Interview with Oleg Balekhov on the topic: The path from an Orthodox priest to a Muslim Shiite, as well as Shiism in Ukraine. https://tureligious.com.ua/yntervyu-s-olehom-balehovym-na-temu-put-ot-

pravoslavnoho-svyaschennyka-k-musulmanynu-shyytu-a-takzhe-shyyzm-v-ukrayne/.

Retrieved: 27 November 2020

Dogra, Sufyan Abid. 2017. Karbala in London: Battle of Expressions of Ashura Ritual Commemorations among Twelver Shia Muslims of South Asian Background. Journal of Muslims in Europe. 6 (2): 158-178.

Fayzrakhmanov, A. Sh. 2009. Muslims in the USSR: Educational-Methodical and Scientific Materials for the Compilation of Textbooks, Lecture Courses, Reading Books, As Well As Students' Research Work. Kazan: Publishing house Spiritual Administration of Muslims of the Republic of Tatarstan.

Flaskerud, Ingvild. 2016. Ritual creativity and plurality: Denying Twelver Shia blood-let practices. In, The Ambivalence of Denial: Danger and Appeal of Rituals. Ute Hüsken \& Udo Simon (eds). Wiesbaden: Harrassowitz.

Khalid, A. 2012. Post-Soviet destinies of Central Asian Islam. Russia and the Muslim World. 3: 135-158.

Lisnyansky, Dina. 2009. Tashayu (Conversion to Shiism) in Central Asia and Russia. Current Trends in Islamist Ideology. 8:108-117.

https://www.hudson.org/content/researchattachments/attachment/1310/lisnyansky_v ol8.pdf. Retrieved: 29 October 2020.

Ministry of Culture of Ukraine. 2012. Information report "On the state and trends of the religious situation and state-confessional relations in Ukraine in 2012. (https://old.irs.in.ua/index.php?option=com_content\&view=article\&id=1212\%3A1\&catid $=51 \% 3$ Astats\&Itemid=79\&lang=uk). Retrieved: 14 December 2020

Muratova, Elmira. 2011. Ukraine, Yearbook of Muslims in Europe. Volume 3: 583-593

Ruthven, M. \& Nanji, A. 2004. Historical Atlas of Islam. Cambridge: Harvard University Press.

https://doi.org/10.24035/ijit.19.2021.191 
Schlatmann, Annemeik. 2017. Towards a united Shia youth community. Journal of Muslims in Europe. 6 (2): 260-276.

Sheikh Said Ismagilov. 2016. Muslim feel Freedom in Ukraine. https://islam.in.ua/ru/intervyu/v-ukraine-musulmane-chuvstvuyut-svobodu-sheyh-saidismagilov. Retrieved: 14 December 2020.

Spellman-Poots, Kathryn. 2012. Manifestations of Ashura among young British Shia. In, Ethnographies of Islam: Ritual Performances and Everyday Practices. Baudouin Dupret, et. al. (eds). Edinburgh: Edinburgh University Press.

State Statistics Committee of Ukraine. 2001. The results of the 2001 All-Ukrainian Population Census, http://2001.ukrcensus.gov.ua/rus/results/general/nationality/. Retrieved: 14 December 2020.

State Statistics Service of Ukraine. 2020. The population of Ukraine, http://database.ukrcensus.gov.ua/PXWEB2007/ukr/news/op_popul.asp. Retrieved: 24 January 2021.

Ukrainian Institute of Strategies of Global Development and Adaptation. 2019. Religion in Ukraine: the latest statistics, https://uisgda.com/ua/religiya-v-ukraini-ostannyastatistika.html. Retrieved: 05 December 2020.

Weiss, Max. 2012. In the Shadow of Sectarianism: Law, Shi'ism, and the Making of Modern Lebanon. The Arab Studies Journal. 20(2): 167-171.

Yunusov, Arif. Statistics of the religious situation in Azerbaijan as of January 1, 2019. http://ipdthinktank.org/Religious\%20statistics\%20Azerbaijan\%202019\%20ru.pdf. Retrieved: 29 November 2020.

Zhussipbek, Galym. 2017. Political Islam in the Central Asian Context: After 25 Years of Independence. Central Asia at 25: Looking Back, Moving Forward - A Collection of Essays from Central Asia. Marlene Laruelle Aitolkyn Kourmanova, ed., Washington: Central Asia Program, Institute for European, Russian and Eurasian Studies Elliott School of International Affairs, The George Washington University. 